\title{
Democracy and Local Autonomy Policy in Indonesia: A Particularist Perspective
}

\author{
Rusnaini \\ Universitas Sebelas Maret \\ Surakarta, INDONESIA \\ rusnaini@staff.uns.ac.id
}

\begin{abstract}
This paper explores the extent to which the discourse of local autonomy policy in Indonesia derived from the concept of democracy is applicable in the case of Daerah Istimewa Yogyakarta (Yogyakarta Special Region). Generally speaking, democracy has been considered a universal concept. However, from a preliminary observation, it was found that a conflict existed in the attempt to applying democracy seen as part of universal values and the desire to preserve the local values of Yogyakarta. Every time when a discourse was put forward to separate the position of the Sultan of Yogyakarta as governor and monarch, the local people tended to reject the election of the governor in Yogyakarta. They wanted the Sultan to be their governor. Using a particulars perspective in the study of governance, this paper argues that democracy can be employed to guide institutional reforms in Indonesia. However, as a concept, it is but a mental construct which is made to draw out meaning from our complex reality. This implies that it should be considered from its usefulness, rather than truthfulness in the case of Yogyakarta. Therefore, the local voice should be carefully considered so that regional autonomy will be less susceptible to failure in its implementation.
\end{abstract}

\section{Keywords- Discourse, Local Autonomy Policy, Democracy, Citizenship.}

\section{DAERAH ISTIMEWA YOGYAKARTA IN THE CONTEXT OF LOCAL AUTONOMY IN INDONESIA}

Citizens in modern democratic societies are entitled to political rights. They are able to elect and to be elected. They are also expected to participate in political activities. As such, democracy has often come to be taken for granted. Political participation in the form of direct voting is often seen as the most efficient system. While this "Universalist perspective", is true in general contexts, certain levels of education and political awareness of both the voters and the representatives are likely to undermine the system. One of the rival arguments, namely a "particulars perspective", is that direct appointment can be equally useful when certain distinctive features, such as historical and cultural aspects, are to be taken into account. This latter system is often seen as undemocratic in the prevailing modern representational politics. However, this paper argues that it can become a useful mechanism to accommodate the public interest or the common good, regardless of the people's ethnic, religious and racial background as well as political allegiance. In a non-competition process, a leader is likely to claim that he or she can exclusively articulate the public interest. What should be taken into account is the need to establish a hire and fire mechanism for the appointed leader or leaders. Thus, he or she is subject to some forms of public accountability. This "tugof-war" between the "Universalist" view of representational system based on the direct voting system in electing a leader and the "particulars" view of the need to accommodate the non-elected leader has loomed large in the local politics of post-Soeharto where direct voting has been in fashion. This paper addresses the following questions: (1) What does Daerah Istimewa Yogyakarta mean in the context of local autonomy in Indonesia?; (2) What are the challenges to local autonomy policy in Daerah Istimewa Yogyakarta?, And (3) What are the challenges to and prospects of democracy and citizenship in Indonesia in the future?

\section{A. The Special Status of Yogyakarta}

One of the most debated cases is the attempt of the former Indonesia's sixth president Susilo Bambang Yudhoyono (popularly known as SBY) to revoke the special status that was given to the Sultan of Yogyakarta (Hamengku Buwono X) in Central Java in 2004. Since the independence of Indonesia in 1945, the Sultanate of Yogyakarta has enjoyed a special status of the new Republic of Indonesia owing to the former Sultan Hamengku Buwono IX's (the father of the current Sultan Hamengku Buwono X) support to the independence of Indonesia and subsequently the revolution period when the Dutch returned to Indonesia in the attempt to reestablish its colonial power. Like his late father (the former Sultan Hamengku Buwono IX), the current Sultan Hamengku Buwono $\mathrm{X}$ has enjoyed the privilege of automatically becoming an unelected provincial governor when he began to hold his royal position in 1989. He has thus served as monarch and governor. Based on the reason that it is undemocratic to appoint a governor, SBY proposed that the governor of Yogyakarta should be elected by the people. 
The reaction towards SBY's maneuver, in the name of democracy, to remove the convention whereby the Sultan inherits the title of governor was overwhelming. In 2008, ten thousands of people went to the streets in Yogyakarta to protest against the government's draft bill. Pamphlets and stickers were put in every corner of Yogyakarta demanding a referendum on the province's future. The majority of the people of Yogyakarta seemed to disagree with the idea of electing their governor. They saw Yogyakarta had been a special place long before and after the Republic of Indonesia was created. More importantly, Sultan Hamengku Buwono X sided with reformers who ousted the dictator Soeharto in 1998. Some political observers saw that SBY might have had some political interest because the Sultan had traditionally allied himself with a rival political party, Golongan Karya (Golkar). Moreover, with his popular and charismatic leadership, the Sultan might become a rival in national politics. If his maneuver was successful, SBY and his Democratic Party was likely to reap the benefit.

\section{B. The Local Autonomy Law}

In Indonesia, public political participation in the general election at either national or local level is governed by law. For election of local leaders, Article 18 Clause [1] of the amended 1945 Constitution mentions that "Governor, regent and mayor as local government head in the province, regency, and municipal, respectively, are elected democratically." This Article is in line with Articles 24 clause [2] and 56 of Law No. $32 / 2004$ that stipulates that a local leader is elected by the populace through a local leader election. The new law concerning the local leader election, Law No. 23 of 2014, also stipulates that local leader is elected through a local leader election.

Since the introduction of the local autonomy policy in Indonesia, there have been so many controversies surrounding it. Two of the most central questions, which have been echoed above, need to be posed in here. First, to what extent does it bring advantages and disadvantages to the political decentralization and administrative decentralization in Indonesia? Secondly, how does it reflect the political decentralization and administrative decentralization concepts?

As prompted above, Yogyakarta was given a special administrative status in the Republic of Indonesia and was called Daerah Istimewa Yogyakarta (the Special Region of Yogyakarta) influenced by two factors: history and culture. It is a special acknowledgment based on the right of the native region as the continuation of the Mataram Kingdom and a tribute to the contribution of its people during the revolutionary period [3] where the Sultan has served as the monarch as well as the governor.

Insofar as issues of special autonomy and political decentralization are concerned, we have not found any similar practices around the world. The issues which are often discussed by scholars in the contemporary studies of public administration, governance and development can range from "between decentralization and public officials' accountability" in Africa [4], "public participation" in Europe [5] to "the relationship between decentralization and responsiveness of public investment to local needs" in Latin America [2]. Yet, we could not find a relatively similar issue that of Yogyakarta in those countries. The same thing can also be applied to Japan. As Hisonari Kato [6] suggests that despite its rich traditional culture, modern Japan of post-Secondary World War has not seen any similar experience as that of Yogyakarta in which the Sultan who has significantly secular and sacred roles.

Two further examples can also be drawn, namely from the sultanates in Indonesia of post-Soeharto period and the sultanates in Malaysia. On one hand, in the post-Soeharto era, Indonesia has seen a revival of the sultanates. [7] points out that there are at least twenty-four sultanates in Kalimantan, Java, Sumatera, and Maluku. During the periods of Sukarno (1945-1966) and Soeharto (19661998), sultanates were not in fashion as they were often seen as carrying feudalistic values which would clash in some ways with modern Indonesia. [7] rightly points out that

Regional autonomy has created arenas for a local political community that hardly existed during the centralizing New Order. Autonomy has brought not merely new administrative arrangements, but a new kind of political struggle requiring new (or newly reinvented) symbols. The autonomy laws focus on the districts (Kabupaten), not on the provinces. The boundaries of these districts often reflect the numerous small kingdoms that were incorporated into the Netherlands Indies by Dutch colonists.

However, the sultans lack the real power. Some have inherited the problems of the past. For example, the Sultan of Pontianak, Syarif Hamid II Alqadrie, was sentenced to ten years in 1953 for siding with the Dutch in the revolution in 1945. Since then, his descendants have never enjoyed the power he had in the colonial time. Despite some other maintain their symbolic popularity, the sultans in Indonesia lack the support from the people. So far they have not gained a real political position, such as being a chief of a district or province.

On the other hand, the constitutional monarchy system in Malaysia is based on the Westminster parliamentary system in which nine of the states in peninsula Malaysia are headed by traditional Malay rulers. Each of them serves as the head of his own state and the religion of Islam in his state. Also, they elect among themselves a federal head of state or "Yang di-Pertuan Agong" [8]. Like other constitutional monarchs around the world, they do not get involved in the actual governance of their states. They have the discretionary power in appointing the chief-minister of their states who commands the majority in the state legislative assembly. This Malaysian experience is not comparable to the uniqueness of Yogyakarta.

If we look at the issue of citizenship and the status of Daerah Istimewa Yogyakarta in the asymmetrical autonomy policy, a different regulation was required in accordance with its historical background, origins and local government's needs and they echo "the principle of unity in diversity (Bhinneka Tunggal Ika)". In the Soeharto era, when the central government's control was very strong, the issue of Yogyakarta as a special region was considered as the domain of the national politics. However, in the post-Soeharto era, it takes various unexpected forms. In fact, this issue has been prompted by 
Michel Foucault in his work on power relations. Foucault [9] suggests that there is no single, but many nationality forms. Thus, it can be stated that the special treatment of Yogyakarta reflects the concept of 'dissension' with various truth principles.

The engagement of various local communities in the planning of special treatment in Yogyakarta shows the uniqueness of the Yogyakarta democracy. Mas'oed and his colleagues [10] reported that there had been a correlation between discourse and practice of pluralism and civic engagement in Yogyakarta resulting in the cultural and political uniqueness among Yogyakarta people. In other words, the political culture of the community plays a role in the democratic processes in the region.

The implementation of the local autonomy policy in Indonesia is considered to be closely related to the political interests of the ruling party, namely the former president SBY's Democratic Party during the issuance of the act (law). Additionally, the social and political condition also affects various policies. The Constitution of the Republic of Indonesia recognizes the existence of special region. Article 18 of the 1945 Constitution (UUD 45) states that: "The state recognizes and respects the units of local government, special in nature and governed by laws." The special status was given to some local governments based on the central government policy to accommodate local people's interest in asymmetrical autonomy policy. Additionally, the 1945 Constitution, the Constitution of Federal Republic of Indonesia (Konstitusi Republik Indonesia Serikat), the Provisional Constitution 1950 (Undang-Undang Dasar Sementara 1950), and the Amended 1945 Constitution recognize the existence of the special region in Indonesian constitutional laws.

During the reform movements in 1998, one of the issues emerged in the country was government decentralization or frequently referred to as local autonomy. The essence of local autonomy is political decentralization (i.e. Devolution) that enabled the local government to administer and to manage its own household affairs. Decentralization is the delegation of government authority to local government to administer and to manage its own governmental affairs in the Unitary Republic of Indonesia (Negara Kesatuan Republik Indonesia). It requires autonomy in local decision making and local democracy.

When the Indonesian government issued the Act Number 22 of 1999 on local government, all of the special regions proposed the draft law of the special status (Rancangan Undang-Undang Keistimewaan or RUUK) to the central government in Jakarta. "It would seem that the most recent literature considers devolution to be the purest or at least the most extensive form of decentralization" [11]. Although Aceh is special, there is not any special name in the nomenclature of the act.

Papua was recognized as a special region. The special treatment of Papua was given in the form on the right to the People's Consultative Assembly of Papua (Majelis Rakyat Papua or MRP) to get seats in legislative bodies and the fiscal balance between the central government and local government. Subsequently, West Papua as a new established province was also recognized as a special region. After that, a special treatment was given to Jakarta as a Special Capital City (Daerah Khusus Ibukota (DKI)), the capital city of Indonesia. Administrative head or the mayor of Jakarta was in his position after appointed by the governor of the Special Capital City. Additionally, there was no Regional People's Representative Council (Dewan Perwakilan Rakyat Daerah or DPRD) in Jakarta City that controlled the performance of mayors in the check and balance mechanism.

Insofar as the regional autonomy issue is concerned, Daerah Istimewa Yogyakarta has its own 'traditional' uniqueness. The emphasis on the appointment and discharge of its local leaders is a case in point. The current province's governor is Sultan Hamengku Buwono (HB) and Vice Governor is Duke Paku Alam (PA), who are, respectively, the heads of the Sultanate of Yogyakarta and Duchy Paku Alaman. According to [3] the special treatment of Yogyakarta is not only related to democracy and non-democracy or democracy versus monarchy, but also to the process of accommodating identity. The process is related to attitude, value and individual and group hopes of democracy and citizenship. This led to the emergence of various organizations at both public and government bureaucracy levels [7] that engage in the issues.

Based on the foregoing description, it is necessary to discuss the concept of regional autonomy as democratic citizenship, which has been implemented differently in different regions, or generally referred to as the asymmetrical local autonomy. In Daerah Istimewa Yogyakarta, regional autonomy has been rendered to the region due to its complex historical and traditional values involving the Sultan. However, in Nangroe Aceh Darussalam and Papua, it relates to the emerging discourse of the local people regarding the issuance of the "Special District" and "Special Region" Acts. For example, the Act of Aceh Special District enables the presence of local political parties and the implementation of Sharia law in the Nangroe Aceh Darussalam province to articulate their special ideological desires. In addition, the act of Papua special autonomy enables the Papua People Consultative Assembly (Majelis Rakyat Papua or $M R P)$ to have a special relationship with the bicamerallike Regional People's Representative Council (DPRD) and the governor and the deputy are the native people of Papua in the special treatment of Papua. There appear to be some inconsistencies in the implementation of democracy in Indonesia. The uniqueness of the local autonomy policy in Indonesia can be seen in the recognition that "Special Region" might be different from others. The asymmetrical local autonomy patterns applied to the government should be "non-equivalent principle" [12].

\section{CHALLENGES TO AND PROSPECT OF DEMOCRACY AND CITIZENSHIP IN THE FUTURE}

Article 18 Clause [7] of the amended 1945 Constitution stipulates that "Governor, regent and mayor, each of which is the head of a province, regency and municipal, are elected democratically." The definition of democracy in here can be interpreted differently. Some people may argue that the local leader election should be conducted directly, but others may argue that it can be conducted either directly or indirectly. The result of the study carried out by the National Defense Institute in 
2007, presented by [13], who was then the Institute's governor, states that indirect governor election is irrelevant with the local autonomy. The reason is that a governor is the government's representative in a particular region and it is the political arm of the President, so that its direct election by the people becomes irrelevant [13]. In addition, [14] point out that:

From a procedural aspect, the direct local leader election is held uniformly in local areas, while to see the quality of direct local leader election, it should be seen from not only its procedure but also its substantive issues, in which each of local areas has its own peculiarity.

The rejection of the election of the local head of Daerah Istimewa Yogyakarta shows that democracy should not be narrowed by public participation in the election in terms of voting. In fact, the concept of modern democracy suggests that citizenship can be seen as a coin with two sides, comprising of rights and obligation. Voting represents only one side of the coin in the practice of democracy, namely an "obligation" of the people to elect their leader [15]. It does not suggest that the rights of the people have automatically been fulfilled, particularly when some irregularities are implicated. The election of the local leader in Yogyakarta is an administrative formality because without this procedure, the legitimacy of the "two functions" of its ruler (which is preferred by the people) would be impossible. In this context, substantial democracy is more important than procedural democracy; otherwise the latter would undermine the social and cultural structure of Yogyakarta. It is unnecessary for us to implement democracy exactly the same as that in other countries because, as we know, it is interpreted differently in various countries depending on their political cultures. Indonesia also has its own experience with democracy consisting of some different concepts in its implementation. Although it is a universal concept, democracy is essentially "culture-bound" [16]. In other words, the social characteristics of the people will give colors to its implementation. An empirical study on the issue is that of Robert Putnam which is entitled "Making Democracy Work: Civic Tradition in Modern Italy" that suggests that in the parts of the globe where people have "civic values", democratic attitudes would develop very well [17].

In fact, Delany [1] has suggested that democracy consists of constitutionalism, pluralism, and citizenship. Constitutionalism represents the rule of law confining the state domain (i.e. the excessive role of the state in the context of social contract). Pluralism refers to the public interest representation. Citizenship represents public participation in government and/or policy making constituting the right and the obligation of state citizens.

Constitutionalism is not the only element of democracy, but there are two other important elements: pluralism and citizenship as suggested [15]. Thus, the understanding of democracy is parallel with that of ethnic diversity, religions, race, custom, and person's mindset so that peoples' sovereignty is not reduced through representative institutions. In other words, it is better for the state not to establish political laws and not to make political policies through representative institutions only. [18] found that normative theory of democracy tends to take different forms of public participation. In the representative democracy model, public participation plays an important role, especially in the election. In associative democracy model, deliberative democracy and participative democracy, and other aspects of public participation are emphasized.

\section{THE CHALLENGES TO LOCAL AUTONOMY POLICY IN DAERAH ISTIMEWA YOGYAKARTA AND THE PROSPECT OF DEMOCRACY AND CITIZENSHIP IN THE FUTURE}

So far, our discussion has shown that the idea of the public identity of Yogyakarta with their collective right is consistent with the demand of democracy and citizenship. It indicates that "the special treatment" of Yogyakarta becomes not only a governmental issue, but also collective rights and communal life that must be recognized in the practice of democracy as it also practiced in other countries. Therefore, democracy should not be used as the reason to deny or to eliminate a local identity or to stigmatize them as typical "Wong Yogya", the people of Yogyakarta. The flexibility in the democracy enables a good understanding about the capability of local mechanism or local wisdom in materializing the ideal of the democracy itself, i.e. People's physical and psychological wellbeing [19]. Democracy is people's ideal. If the local people of Yogyakarta want the Sultan to be governor, it is "democracy of Mataram style", a sort of the social construction of Yogyakarta people. The case of Daerah Istimewa Yogyakarta shows that decentralization policy in Indonesia is indeed dominated by local values. Kato [6] contents that Yogyakarta is a test case of what he calls as the "local civilization" to create a society of peace promoting the welfare of the people. However, he also warns that only time will tell whether such practice may fall into prey one day to dictatorship or tyranny.

To understand democracy as described above in the implementation of the asymmetric local autonomy policy, three statuses defining citizenship should be considered: The first status is the legal status of a citizen, meaning that a citizen is a legal being who acts legally and has the right to protection as state citizen. The second status refers to citizens as political agents actively taking a part in political institutions. The third status relates to the membership of citizens in the political community, resulting in certain identity [6]. It is expected that with the understanding of citizenship statuses described above, the government will give its people a space to engage in the legislating process and public policy making so that the prospect of democracy and citizenship will be better secured.

\section{CONCLUSIONS}

This paper evaluates the implementation of the concepts of democracy and citizenship in relation to the local autonomy policy in the post-Soeharto era in Daerah Istimewa Yogyakarta. It argues that the special status given to Daerah Istimewa Yogyakarta has not been accompanied by a rigorously democratic policy in the election of its governor. Such inconsistency tends to pose some problems. 
Firstly, the local autonomy policy has raised concerns among various sections in the society. However, until now, these issues have not been addressed in the act or law related to democracy and citizenship. Thus, it poses challenges for us to question the implementation of the policy. Secondly, this paper has revealed some weaknesses of the decentralization concept in the amended version of the 1945 Constitution (UUD 1945) because it has not been able to accommodate the needs of the Indonesian people exemplified by the implementation of the local autonomy policy in Daerah Istimewa Yogyakarta. Consequently, the differences of practice of democracy suggest that understanding pluralism as a public representation in the asymmetrical local autonomy policy is very important and urgent. Our lives have been characterized by the increase of cultural pluralism in the last few decades. This poses challenges to the need for the reformulation of the policy in Indonesia. Greater participation of citizens in it should also be encouraged.

\section{REFERENCES}

[1] Delanty G. Communitarianism and citizenship. IN: Isin EF, Turner, BS. Editors. Handbook of citizenship studies. London: Thousand Oaks; 2002.p. 159-174

[2] Faguet JP. Does decentralization increase government responsiveness to local needs? evidence from Bolivia, J Publ Econ. 2004; 88: 867-893.

[3] Mas'udi W. Komodifikasi identitas: reproduksi wacana asli san pendatang dalam debat keistimewaan DIY. IN: Setyanto WP, Pulungan H. Editors. Politik identitas: agama, etnisitas dan ruang/space dalam dinamika politik di Indonesia dan Asia Tenggara. Salatiga: Percik; 2009:304-314.

[4] Antwi-Boasiako KB. Public administration: local government and decentralization in Ghana. J Afri Admin Stud and Dev. 2010; 2 (7): 166-175.

[5] Lowndes V, Pratchett L, Stoker G. Trends in public participation: part 1- local government perspective, Publ Admin. 2000;79 (1): $205-222$.
[6] Kato H. Local civilization and political decency: equilibrium and the position of the sultanate in Java, Comp Civiliz Rev, 66, Spring, 2001: 4557.

[7] Van Klinken G. Return of the sultans. Inside Indonesia, 78 (AprilJune), 2004. Cited 2015 November 18. [ about 1 screen] Available from: www.insideindonesia.org/return-of-the-sultans

[8] Hooker VA short history of Malaysia: linking east and west, St Leonard: Allen \& Unwin; 2003.

[9] Abercrombie N, Hill S, Turner BS. The Penguin dictionary of sociology, 4th edition. London: Penguin Book; 2000.

[10] Mas'oed M, Panggabean SR, Azca N. Social resources for civility and participation, the case of Yogyakarta, IN: Hefner RW. Editors. The politics of multiculturalism, pluralism and citizenship in Malaysia, Singapore and Indonesia. Honolulu: University of Hawaii Press; 2001:119-140.

[11] White S. Government decentralization in the 21st century, a literature review. [Internet], Washington DC: Center for Strategic \& International Studies.Cited 2012 December 10. [ about 1 screen] Available from: www.csis.org.

[12] Maksum. Otonomi Yogyakarta. IN: de Rosari BL Editor. Monarki Yogya inkonstitusional? Jakarta: Kompas; 2011:159163.

[13] Muladi. Pilkada gubernur tidak relevan dengan otonomi daerah. Cited 2012 September 20. [about 1 screen] Available from: http://otda.bappenas.go.id.

[14] Mariana D, Paskarina C. Pemilihan kepala daerah secara langsung: Melahirkan pemerintahan yang demokratis? J Govern.2005; 1(3) 2005: 1-14.

[15] Kalidjernih FK Pusparagam konsep dan isu kewarganegaraan. Bandung: Widya Aksara Press; 2011.

[16] Gaffar A. Politik Indonesia transisi menuju demokrasi. Yogyakarta: Pustaka Pelajar; 2006.

[17] Michels A. Debating democracy: the Dutch case. Acta Polit, V.43, 2008: 472-492.

[18] Susan N. Yogyakarta dan kacamata kuda IN: BL de Rosari (Editor). Monarki Yogya inkonstitusional? Jakarta: Kompas; 2011: 169-173

[19] Winataputra US. Jatidiri pendidikan kewarganegaraan sebagai wahana sistemik pendidikan demokrasi. Unpublished. doctoral dissertation. Postgraduate Program, Universitas Pendidikan Indonesia; 2001. 